\title{
Pesticidal Effects of Extracts from Hyptis suaveolens and Hyptis spicigera on Cowpea Weevils
}

\author{
Sekyere Paul Appiah ${ }^{1}$, Mbatchou Valentine Chi ${ }^{1}$, Dickson Adom ${ }^{*}$, Felix Ayisi \\ Asiedu $^{1}$
}

\author{
${ }^{1}$ Department of Science, Serwaa Nyarko Girls’ High School, Kumasi, E-mail: ksekyerepaul@gmail.com Tel: +233209065883 \\ ${ }^{2}$ Department of Applied Chemistry and Biochemistry, University for Development Studies E-mail: vmbatchou@uds.edu.gh Tel: \\ $+23354782308$ \\ ${ }^{* 3}$ Department of Educational Innovations in Science and Technology, Kwame Nkrumah University of Science and Technology, \\ Kumasi, Ghana, E-mail: adomdick2@gmail.com Tel: +233508149965 \\ ${ }^{4}$ Department of Chemistry, Kwame Nkrumah University of Science and Technology, Kumasi, Ghana, E-mail: \\ kwameasieduayisi@gmail.com Tel: +233244985350 \\ *Corresponding author's Email: adomdick2@gmail.com
}

\begin{abstract}
This experimental research was conducted with the view of determining the effectiveness of Hyptis suaveolens and Hyptis spicigera extracts on cowpea seeds in deterring the feeding habit and life span of cowpea weevils. Masses of 400 and 500 grammes of pulverized samples of the two plants, Hyptis suaveolens and Hyptis spicigera were separately extracted by percolation with 2200 millilitres of $95 \%$ ethanol respectively. The percolates were evaporated to dryness at room temperature to give crude extracts of both plants which were each subjected to a partition process. Soluble solvent extracts of the two plants were applied on cowpea seeds and subjected to cowpea weevils by two-choice feeding deterrent method. The chloroform soluble extracts were found to be most active extracts of both plants with the least percentage consumption indices and higher percentage mortalities. This was a clear indication that these chloroform soluble extracts contained most of the toxic component(s) of the plants which can be used to protect cowpea seeds to some period of time. The study tasks the Ministry of Food and Agriculture to consider providing funding and further research into the use of the pesticides from these plant extracts to maintain the buoyancy ofbiodiversity as well as the environment in Ghana.
\end{abstract}

Keywords- Pesticidal Effects, Plant Extracts, Hyptis suaveolens, Hyptis spicigera, Environmental Conservation.

\section{INTRODUCTION}

A pesticide is any substance used to kill, repel or control certain forms of plant or animal life that are considered to www.ijeab.com be pests. Elemental sulphur dusting against lice in 2000 B.C. is the first recorded use of pesticides (Fishel, 2013). Pesticides include herbicides for destroying weeds, and other unwanted vegetation, fungicides used to prevent the growth of molds and mildew, disinfectants for preventing the spread of bacteria, and compounds used to control mice and rats (Leroy et al, 2009). Bio-pesticide such as pyrethrum and rotenone, from the roots of tropical vegetables, was introduced in the $19^{\text {th }}$ century (Miller, 2002).

The behavior of a pesticide in the environment depends on its stability, physico-chemical properties, the nature of the medium in which it is applied, the organisms present in the soil, and the prevailing climatic conditions (Singh \& Walker, 2006). Because of the wide spread use of agricultural chemicals in food production, people are exposed to low levels of pesticide residues through their diets. Scientists do not yet have a clear understanding of health effects of these pesticide residues. Results from agricultural study, an on-going study of pesticide exposures in farms, show that farmers who used agricultural pesticides experienced an increase in headaches, fatigue, insomnia, dizziness, hand tremors, and other neurological symptoms (Hipkins et al., 1996).

It has been established that pesticides could become a nuisance if they are misused or continuously applied. Some of the negative effects of pesticide misuse include undesirable residue accumulation in food crops (Owens et al., 2010). Evidence suggests that children are particularly susceptible to adverse effects from exposure to pesticides, including neuro-developmental effects. People may also be

Page | 1691 
exposed to pesticides used in a variety of settings including homes, schools, hospitals and workplaces. (Knutson, 2009). Pesticides can be classified as synthetic pesticides or biological pesticides (bio-pesticides), although the distinction can sometimes be blurred (Miller, 2004). Pesticides are used to control harmful organisms such as mosquitoes that transmit parasites which cause potentially deadly diseases like yellow fever and malaria. They can kill invasive weeds in parks and wilderness, and also kill organisms that destroy storage products which may cause environmental damage (Eurekalert, 2009). Pesticides are used in grocery stores and food storage facilities to manage rodents and insects that infest food such as grains (Kellogg et al., 2000).

Each use pesticide carries some associated risks. Proper pesticide use decreases these associated risks to a level deemed acceptable by pesticide regulatory agencies such as the United States Environmental Protection Agency and Pest Management Regulatory Agency of Canada. Strict pesticide regulation and enforcement mechanism are put in place to ensure its safe use and proper handling. The control schemes further ensure that approval for the sale and use of pesticide is based on scientific data that support its effectiveness against target pests and that it is not unduly hazardous to human health and the environment (GloverAmengor \& Tetteh, 2007).

The application of pesticides on crops can save farmers some money by preventing crop losses to insects and other pests. In the United States, farmers get an estimated fourfold return of money they spend on pesticides (Kiniuki et al., 2001). One study found that not using pesticides reduced crop yields by about $10 \%$ and another study, conducted found that a ban on pesticides in the United States may result in a rise of food prices, loss of jobs, and an increase in world hunger (Knutson, 1999).

The $19^{\text {th }}$ century saw the introduction of two more natural pesticides, pyrethrum which is derived from chrysanthemums and rotenone which is derived from the roots of tropical vegetables (Miller, 2002). In 1939, Paul Muller discovered that diphenyl dichloro trichloroethane (DDT) and other synthetic compounds were very effective pesticides. His discovery prompted many manufacturers in the 1940's to produce synthetic pesticides in large amounts because they were widely used (Daly et al., 1998). The use of DDT and othersynthetic chemicals as pesticides began to pose serious threats to human health and the environment. In the 1960's, it was discovered that DDT was preventing many birds from reproducing, which was a serious threat to biodiversity (Lobe et al., 2005). The agricultural use of DDT, lindane, and karate, is now banned under the Stockholm Convention on Persistent Organic Pollutants, but these pesticides are still used in some developing countries to store grains and prevent tropical diseases by spraying on interior walls and fields to kill or repel insects (Lobe, 2006). Surveys conducted in vegetable growing areas in Ghana identified lindane, karate, unden and dithane as the most used pesticides by farmers. However, the agricultural use of these compounds has been banned and the pharmaceutical use of lindane is prohibited in some countries because it causes damage to the central nervous system and weakens the immune system (Glover-Amengor \& Tetteh, 2007).

Residues of pesticide can be found in most consumable items such as, vegetables, fruits, fish and some processed foods made from them making them unsafe (Amoako, 2010). A study to assess the residue levels of selected pesticides on tomato crops in Ghana revealed that pesticide residues were indeed present (Essumang et al., 2008). Another research was carried out to determine and compare the levels of vulnerability of the Ghanaian population to pesticides and faecal coliform contamination through the consumption of fresh vegetables produced in intensive urban and peri-urban waste water irrigation which revealed that the public health of Ghanaians are threatened from pesticide because many vegetables are consumed in their fresh forms (Amoah et al., 2006)

These cause serious health effect and environmental problems. The cumulative effects resulting from the use of these synthetic chemical compounds had diverted the attention of most chemists and environmentalists to the search of compounds from natural sources which are directly or indirectly non-toxic to humans, wildlife and the ecosystem. Leaves, seeds, barks and roots of plants have been investigated by many researchers by isolating, identifying and screening for chemical compounds that deter and inhibit growth of pest (Oparaeke, 2007). The objective of the research is to deduce the efficacy of Hyptis suaveolens and Hyptis spicigera extracts on cowpea weevil (Callosobruchus maculatus) in terms of anti-feedant property and mortality rate. It is the aim of the work to identify the most active extracts from the two plants which could lead to the isolation of active compounds that could serve as pesticides. The scope of this research involves the testing of components obtained from Hyptis suaveolens and Hyptis spicigera on cowpea weevils using cowpeas in a two-choice feeding deterrent bioassay.

\subsection{Hyptis suaveolens Lam (Lamiaceae)}

Hyptis suaveolens is a dicotyledonous plant and belongs to the family Lamiaceae (Leroy et al, 1979). It is an annual shrub or an erect branched herb with white pilose, strongly aromatic stems, up to 120 centimeters high, the leaves are ovate with the base rounded to 5.5 centimeters long and 40 
millimeters broad. The flowers are blue to purple with the corolla 5.5 millimeters long and 6 millimeters across in a dense raceme of cymules. It has an inflorescence leaves with lateral cymules and a few flowers. The petals are up to 6 millimeters long while the calyx-teeth are equal in size (Chopra et al., 1956).The plant is usually found growing around abandoned construction sites and refuse dumps in tropical countries (Yoganarasimhan, 2000).

The uses of Hyptis suaveolens are categorized into medicinal and other uses. Hyptis suaveolens (L.) Poit; [Lamiaceae] can cause infertility; it is anti-inflammatory and also has anti-plasmodial properties (Sharma et al, 2013). Almost all parts of this plant are being used in traditional medicine. Its leaves are utilised as a stimulant and as a cure for parasitic cutaneous diseases in India (Mandal et al., 2007). A decoction prepared from the leaves of the plant is drunk to combat indigestion of food in the stomach in some parts of Senegal, whereas in Ivory Coast, the same part of the plant is pounded, mixed with water and administered to children as enema for the treatment of gastrointestinal troubles (Bouquet, 1969). The crude leaf extract of this plant is used as relief to colic and stomachache, while fumes of its dried leaves are used to control insect pests of stored grains and as a mosquito repellent (Kirtikar et al., 1991). In Mali, the liquid obtained from the leaves by squeezing with the fingers is applied on the nose against headaches and catarrh (Chopra, 1956) whereas in northern parts of Nigeria, Kenya and Gabon, a concoction of the leaves and stem is drunk to cure piles and as a remedy to abortion in pregnant women (Dalziel, 1937). In Mali, Nigeria and Senegal, the leaves and stems are used to bath dead bodies so as to prevent decomposition (Chopra, 1956). The same parts of the plant are used as antiinflammatory and anti-fertility agents in India. In Ivory Coast, the stem is chewed and the extract from it is swallowed as treatment for stomach upsets (Kerharo \& Bouquet, 1950).

A decoction prepared from the roots is used as an appetizer and is reported to contain urosolic acid, a natural HIVintegrase inhibitor. The shoot-tips are eaten in India, and in Thailand they are added to food as flavouring (Chatterjee $e t$ al., 1997). Biological activities of the leaves of Hyptis suaveolens have been reported in literature. The steam distillation and petroleum ether extracts of the leaves have displayed antifungal activity on Aspergillus niger, Fusarium oxysporum and Helminthosporium oryzae. These same extracts have also exhibited a broad spectrum of antibacterial activity on Bacillus subtilis, Pseudomonas aeruginosa and Micrococcus luteus. Hyptis suaveolens is found to contain some essential oils, alkaloids, flavonoids, phenols, saponins, terpenes, and sterols, for example diterpenes: suaveolic acid, suaveolol, methyl suaveolate, steroids: $\beta$-sitosterol, Oleanolic acid, ursolic acid, $3 \beta$ hydroxy-lup-12-en- 28-oic acid (Chukwujekwu et al., 2005).Essential oils from the leaves have presented higher antimicrobial effects on Mucor species when compared to ketoconazole (Malele et al., 2003). Works have been published on the isolation of terpenoids and steroids from the plant. Investigations on the aerial parts of this plant have led to the characterisation of a new pentacyclic triterpene (Murkherjee et al., 1984). Essential oils from the leaves have indicated the existence of compounds such as $\beta$ caryophyllene, $\beta$-elemene, 1,8-cineole, sabinene, trans- $\alpha$ beryamotene, spathulenol and bicyclogermacrene (Malele et al., 2003; Mandal et al., 2007; Corey et al., 1964).

\subsection{Hyptis spicigera Lam (Lamiaceae)}

Hyptis spicigera is also dicotyledonous and belongs to the same family as Hyptis suaveolens. The plant is an erect shrub of 120 to 150 centimeters tall, having a stem of 6 to 8 centimeters long with a diameter of 2 to 3 centimeters. It has a terminal inflorescence with either a dense cylindrical or ovoid cylindrical spike which consists of very small white/mauve flowers (Birkill, 1985).Hyptis spicigera can be found growing on roadsides, waste places and cultivated land, but mostly on dump sites (Parson et al, 1992). The plant is commonly seen growing across Senegal to West Cameroun (Kerharo \& Bouquet, 1950). The uses of Hyptis spicigera can be categorized into nutritional, medicinal, social and others. The leaves and seeds are used in Gabon to prepare sauces and these parts of the plant serve as condiments and flavours in foods. The leaves, flowers and seeds are orally consumed in Senegal and Nigeria for the treatment of diarrhoea, dysentery, nasopharyngeal and cutaneous infections (Birkill, 1985). The leaves are squeezed with the fingers and drops of the liquid obtained are poured in the nose to treat catarrh and severe headaches. In Brazil, the leaves are dried and pounded and applied on the skin as treatment for eczema (Chopra, 1956). In Northern Ghana, the leaves are placed in guinea corn barns to prevent weevils from perforating grains (Dalziel, 1937), while in Senegal, the entire plant is known as dead plant because it is used to preserve dead bodies from decomposition (Kerharo \& Bouquet, 1950). The plant has been used to control Striga hermonthica infestation which predominates on maize farms. This finding has improved the yield of crops in Striga-prone environment (Orthira et al., 2008). Extracts from the plants have shown some biological activities. Ethanol extracts from the leaves of the plant have been tested on Callosobruchus maculatus $F$, a pest of stored cowpea and have proved active (Sanon et al., 2006).Leaf extracts of Hyptis spicigera and Parkia 
biglobosa have shown activity against root knot-nematodes (Yussuf et al., 2006).Structural elucidation had also shown the presence of some compounds in the plant. Essential oils extracted from the stem and leaves of the plant have indicated the presence of $\beta$-caryophyllene, $\mathrm{C}_{16}$ and $\mathrm{C}_{18}$ fatty acid methyl esters which could serve as flavours (Onayade et al., 2003; Leonti et al 2008).

Research works have provided understanding of the chemistry of some plants of the lamiaceae family of which Hyptis suaveolens and Hyptis spicigera are among. The mode of action for these plants were analysed and has shown that these plants can be used reliably and safely to treat grains and legumes when stored in small quantities. In a Rural Participatory Appraisal (RPA) survey conducted in semi-arid regions, Hyptis suaveolens and Hyptis spicigera were among sixteen plants identified as grain protectant (Brice et al., 1996).

\subsection{Weevils}

Weevils are generally divided into two major divisions, the Orthoceri or primitive weevils, and the Gonatoceri or true weevils. E. C. Zimmerman proposed a third division, the Heteromorphi, for several intermediate forms. Primitive weevils are identified by their straight antennae, while true weevils have elbowed (geniculate) antennae. The elbow occurs at the end of the scape (first antennal segment) in true weevils, and the scape is usually much longer than the other antennal segments. Some exceptions occur. Nanophyini are primitive weevils (with very long trochanters) but have long scapes and geniculate antennae (Zimmerman, 1994). Weevils are often found in dry foods including nuts and seeds, cereal and grain products. In the domestic setting, they are most likely to be observed when a bag of flour is opened, although they will happily infest most types of grain including wheat and barley. Their presence is often indicated by the granules of the infested item sticking together in strings, as if caught in a cobweb. If ingested, Escherichia coli infection and other diseases can be contracted (Drees \& Jackmam, 1999).

\subsection{Callosobruchus maculatus (Fibricius)}

They are commonly called cowpea weevils and their adults are $\frac{1}{8}$ inch long and slightly elongated when compared to the typical rounded appearance of other members of the bruchids family. Although weevil-like, they are not true weevils and do not have heads prolonged into a long "snout." Wing covers (elytra) are marked with black and gray and there are two black spots near the middle of their wing covers. The elytra are short, leaving the last segment of the abdomen exposed. This last abdominal segment also has two visible black spots. The larva is whitish and www.ijeab.com somewhat C-shaped with a small head (Philips et al, 1996). There are other bruchids which include stored product pests and species that attack plants in the wild. The bruchids that feed on stored products include: the pea weevil, Bruchus pisorum (Linnaeus), which feeds primarily on green peas; the broad bean weevil, B. rufimanus (Boheman), which prefers kidney beans and lima beans; and the common beanweevil, Acantoscelides obtectus (Say). Adult bruchids sometimes can be quite common on flowers in the spring time. Eggs laid by females hatch in 5 to 20 days. Larvae typically feed inside the cowpea, taking from 2 weeks to 6 months to develop before pupating there. The adults may live for seventeen days and six or seven generations may occur per year. Mouthparts are for chewing. They prefer dried cowpeas but will attack other beans and peas in storage. Adults move about readily and can infest seeds in the field, but can also breed continuously in stored dry cowpeas. Larvae typically develop inside the dried peas. Larvae chew near the surface and leave a thin covering uneaten which appears as a window (Nojima et al, 2007).

\section{METHODOLOGY}

The study utilized the experimental research. The equipments used in the research include: digital chemical balance, separating funnels, beakers (600 and 300ml), retort stand, funnels, Whatmanns filter paper, vials, micro litre syringes, cowpea seeds, cowpea weevils (Callosobruchusmaculatus F.), screen cages demarcated into compartments, Winchester bottles, Aluminum foil. The reagents included 95\% ethanol, methanol, chloroform, petroleum ether and distilled water. The reagents used were analytical grades bought from Timster Laboratory Suppliers Limited. Two plants, Hyptis suaveolens Lam and Hyptis spicigera Lam were used for the experiment due to their local uses in some African countries and Northern Ghana in particular. Both plants were randomly harvested behind the Microbiology Laboratory of University for Development Studies, Navrongo Campus in November, 2008. The entire plants were separately air dried for twenty one days and later pulverized with the aid of a clean mortar and a pestle. The pulverized samples were stored in cleaned air-tight containers and kept in a cool dry place.

\subsection{Extraction Procedure}

Masses of 400 and 500 grammes of pulverized samples of the two plants, Hyptis suaveolens and Hyptis spicigera were separately extracted by percolation with 2200 millilitres of 95\% ethanol respectively for two weeks. The percolates were evaporated to dryness at room temperature to give crude extracts of both plants which were each subjected to a partition process. 


\subsection{Partition Procedure}

Crude extracts obtained as described above were partitioned between chloroform and distilled water (100, 1:1) using separatory funnels. The chloroform soluble fractions and the distilled water soluble fractions for each plant sample were separately evaporated to dryness at room temperature. The chloroform soluble residues were later partitioned between methanol and petroleum ether (100, 1:1). The methanol soluble fraction and the petroleum ether soluble fractions were also separated and concentrated. The residues derived in the whole process were transferred into vials and used in a two- choice cowpea weevil bioassay (Fatope et al., 1995).

\subsection{Two-Choice Cowpea Weevil Bioassay}

$10 \mathrm{mg}$ of test extracts were weighed and dissolved in $1 \mathrm{ml}$ of methanol. $250 \mu \mathrm{l}$ of the solution formed was poured into a vial and kept overnight to evaporate to dryness. $5 \mathrm{ml}$ of methanol was later added to the vial to re-dissolve the residue obtained and 40 cowpea seeds were immersed in the solution for a few seconds. The vial and its contents were allowed to dry at room temperature. Control cowpea seeds were introduced into $5 \mathrm{ml}$ of methanol in a similar manner as the treated seeds and the treated seeds were prepared in duplicates. Both the treated and control cowpea seeds were separately placed in compartments demarcated by cardboards at the bottom of a screen cage and the seeds were infested with weevils. At the end of two weeks interval, the perforated and unperforated cowpea seeds, and dead weevils were counted (Fatope et al, 1995).

The percentage consumption index (\% C.I) and mortality were calculated using the following formulae:

$$
\begin{gathered}
\% \text { C.I }=\frac{\% \text { treated cowpea seeds perforated }}{\% \text { treated cowpea seeds perforated }} \times 100 \\
\% \text { Mortality }=\frac{\% \text { test mortality }-\% \text { control mortality }}{100-\% \text { control mortality }} \times 100
\end{gathered}
$$

III. RESULTS AND DISCUSSIONS

\begin{tabular}{|c|c|c|c|c|c|c|c|}
\hline \multirow{2}{*}{$\begin{array}{l}\text { SOLUBLE } \\
\text { SOLVENT } \\
\text { EXTRACT/ } \\
\text { FRACTION }\end{array}$} & \multirow{2}{*}{$\begin{array}{l}\text { CONCENTRATION } \\
(\mu \mathrm{g} / \mathrm{ml})\end{array}$} & \multicolumn{2}{|c|}{$\begin{array}{l}\text { NUMBER OF } \\
\text { PERFORATED SEEDS }\end{array}$} & \multirow{2}{*}{$\begin{array}{l}\text { \% TREATED } \\
\text { SEEDS } \\
\text { PERFORATED }\end{array}$} & \multirow{2}{*}{$\begin{array}{l}\% \text { CONTROL } \\
\text { SEEDS } \\
\text { PERFORATED }\end{array}$} & \multirow{2}{*}{$\begin{array}{l}\% \\
\text { CONSUMPTION } \\
\text { INDEX ( } \% \text { C.I) }\end{array}$} & \multirow{2}{*}{$\begin{array}{l}\text { MEAN \% } \\
\text { CONSUMPTION } \\
\text { INDEX }\end{array}$} \\
\hline & & TREATED & CONTROL & & & & \\
\hline \multirow{3}{*}{ ETHANOL } & 500 & 2 & 9 & 10 & 45 & 18.18 & \multirow{3}{*}{26.29} \\
\hline & 250 & 3 & 9 & 15 & 45 & 25.00 & \\
\hline & 125 & 5 & 9 & 25 & 45 & 35.71 & \\
\hline \multirow{3}{*}{ CHLOROFORM } & 500 & 0 & 11 & 0 & 55 & 0.00 & \multirow{3}{*}{7.14} \\
\hline & 250 & 0 & 11 & 0 & 55 & 0.00 & \\
\hline & 125 & 3 & 11 & 15 & 55 & 21.42 & \\
\hline \multirow{3}{*}{$\begin{array}{l}\text { DISTILLED } \\
\text { WATER }\end{array}$} & 500 & 1 & 10 & 5 & 50 & 9.09 & \multirow{3}{*}{21.83} \\
\hline & 250 & 3 & 10 & 15 & 50 & 23.08 & \\
\hline & 125 & 5 & 10 & 25 & 50 & 33.33 & \\
\hline \multirow{3}{*}{$\begin{array}{l}\text { PETROLEUM } \\
\text { ETHER }\end{array}$} & 500 & 1 & 9 & 5 & 45 & 10.00 & \multirow{3}{*}{21.92} \\
\hline & 250 & 3 & 9 & 15 & 45 & 25.00 & \\
\hline & 125 & 4 & 9 & 20 & 45 & 30.76 & \\
\hline \multirow{3}{*}{ MIETHANOL } & 500 & 1 & 8 & 5 & 40 & 11.11 & \multirow{3}{*}{21.48} \\
\hline & 250 & 2 & 8 & 10 & 40 & 20.00 & \\
\hline & 125 & 4 & 8 & 20 & 40 & 33.33 & \\
\hline
\end{tabular}

Table.1: Feeding deterrent activity of Hyptis suaveolens extracts on cowpea weevils

From table 1, there were zero \% consumption indices for both the 250 and $500 \mu \mathrm{g} / \mathrm{ml}$ concentrations of the chloroform soluble fraction of Hyptis suaveolens. This implies that the solvent soluble fraction protected the cowpeas from being infested by the weevils. The $125 \mu \mathrm{g} / \mathrm{ml}$ concentration of the chloroform soluble fraction recorded the least consumption index of $21.42 \%$ when compared to all the other tested extracts of the same concentration. This clearly gives a clue that the chloroform soluble fraction of Hyptis suaveolens contains the most active components which prevent the weevils from feeding on the cowpeas. From the same table, the ethanol soluble extract at 125 and 
$500 \mu \mathrm{g} / \mathrm{ml}$ concentrations recorded the highest consumption indices of 35.71 and $18.18 \%$ respectively when compared to all the other tested soluble fractions at these concentrations. This is an indication that the ethanol soluble extract is the least active in terms of deterring the weevils from feeding on the cowpeas. A contributing factor to the least activity of the ethanol soluble extract is the presence of components or impurities in its content which mask its active ingredients, thus preventing it from exhibiting its complete anti-feeding property.

Table.2: Feeding deterrent activity of Hyptis spicigera extracts on cowpea weevils

\begin{tabular}{|c|c|c|c|c|c|c|c|}
\hline \multirow{2}{*}{$\begin{array}{l}\text { SOLUBLE } \\
\text { SOLVENT } \\
\text { EXTRACT/ } \\
\text { FRACTION }\end{array}$} & \multirow{2}{*}{$\begin{array}{l}\text { CONCENTRATION } \\
(\mu \mathrm{g} / \mathrm{ml})\end{array}$} & \multicolumn{2}{|c|}{$\begin{array}{l}\text { NUMBER OF } \\
\text { PERFOR.ATED SEEDS }\end{array}$} & \multirow{2}{*}{$\begin{array}{l}\% \text { TREATED } \\
\text { SEEDS } \\
\text { PERFORATED }\end{array}$} & \multirow{2}{*}{$\begin{array}{l}\text { \% CONTROL } \\
\text { SEEDS } \\
\text { PERFORATED }\end{array}$} & \multirow{2}{*}{$\begin{array}{l}\% \\
\text { CONSUMITION } \\
\text { INDEX }(\% \text { C.I) }\end{array}$} & \multirow{2}{*}{$\begin{array}{l}\text { MEAN } \% \\
\text { CONSUMIPTION } \\
\text { INDEX }\end{array}$} \\
\hline & & TRE.ATED & CONTROL & & & & \\
\hline ETHANOL & $\begin{array}{l}500 \\
250 \\
125\end{array}$ & $\begin{array}{l}0 \\
3 \\
4\end{array}$ & $\begin{array}{l}8 \\
8 \\
8\end{array}$ & $\begin{array}{l}0 \\
15 \\
20\end{array}$ & $\begin{array}{l}40 \\
40 \\
40\end{array}$ & $\begin{array}{l}0.00 \\
27.27 \\
33.33\end{array}$ & 20.20 \\
\hline CHLOROFORM & $\begin{array}{l}500 \\
250 \\
125\end{array}$ & $\begin{array}{l}0 \\
1 \\
3\end{array}$ & $\begin{array}{l}9 \\
9 \\
9\end{array}$ & $\begin{array}{l}0 \\
5 \\
15\end{array}$ & $\begin{array}{l}45 \\
45 \\
45\end{array}$ & $\begin{array}{l}0.00 \\
10.00 \\
25.00\end{array}$ & 11.67 \\
\hline $\begin{array}{l}\text { DISTILLED } \\
\text { WATER }\end{array}$ & $\begin{array}{l}500 \\
250 \\
125\end{array}$ & $\begin{array}{l}1 \\
2 \\
6\end{array}$ & $\begin{array}{l}11 \\
11 \\
11\end{array}$ & $\begin{array}{l}5 \\
10 \\
30\end{array}$ & $\begin{array}{l}55 \\
55 \\
55\end{array}$ & $\begin{array}{l}8.33 \\
15.34 \\
35.29\end{array}$ & 19.65 \\
\hline $\begin{array}{l}\text { PETROLEUM } \\
\text { ETHER }\end{array}$ & $\begin{array}{l}500 \\
250 \\
125\end{array}$ & $\begin{array}{l}1 \\
3 \\
4\end{array}$ & $\begin{array}{l}8 \\
8 \\
8\end{array}$ & $\begin{array}{l}5 \\
15 \\
20\end{array}$ & $\begin{array}{l}40 \\
40 \\
40\end{array}$ & $\begin{array}{l}11.11 \\
27.27 \\
33.33\end{array}$ & 23.90 \\
\hline METHANOL & $\begin{array}{l}500 \\
250 \\
125\end{array}$ & $\begin{array}{l}1 \\
3 \\
4\end{array}$ & $\begin{array}{l}10 \\
10 \\
10\end{array}$ & $\begin{array}{l}5 \\
15 \\
20\end{array}$ & $\begin{array}{l}50 \\
50 \\
50\end{array}$ & $\begin{array}{l}9.09 \\
23.07 \\
28.57\end{array}$ & 20.24 \\
\hline
\end{tabular}

From table 2, the chloroform soluble fraction of Hyptis spicigera presented the least consumption indices at the tested concentrations when compared to all the other soluble extracts or fractions. Hence, it is a clear indication that the chloroform soluble fraction contains the most active component(s) of the plant and it is capable of inhibiting the feeding habit of the weevils.

On the contrary, the petroleum ether soluble fraction of Hyptis spicigera gave the highest average consumption index of $23.90 \%$ when compared to those of all the other tested extracts or fractions. Therefore, it can be explained that the petroleum ether soluble fraction contains the least active component(s) of the plant which deter the weevils from feeding on the cowpeas.

Results from table 3 present the chloroform soluble fraction of Hyptis suaveolens with the highest average mortality of $40.74 \%$ and the ethanol soluble extract with the least average mortality of $29.16 \%$. These two values reveal that the chloroform soluble fraction contains the most active component(s), while the ethanol soluble extract contains the least active component(s) of the plant which caused the dead of the weevils. 
Table.3: Effects of Hyptis suaveolens extracts on the mortality rates of cowpea weevils

\begin{tabular}{|c|c|c|c|c|c|c|c|}
\hline $\begin{array}{l}\text { SOLUBLE } \\
\text { SOLVENT } \\
\text { EXTRACT/ } \\
\text { FRACTION }\end{array}$ & $\begin{array}{l}\text { CONCENTRATION } \\
(\mu \mathrm{g} / \mathrm{ml})\end{array}$ & $\begin{array}{l}\text { TEST } \\
\text { MORTALITY }\end{array}$ & $\begin{array}{l}\text { CONTROL } \\
\text { MORTALITY }\end{array}$ & $\begin{array}{l}\% \\
\text { TEST } \\
\text { MORTALITY }\end{array}$ & $\begin{array}{l}\% \\
\text { CONTROL } \\
\text { MORTALITY }\end{array}$ & $\begin{array}{l}\% \\
\text { MORTALITY }\end{array}$ & $\begin{array}{l}\text { MEAN } \\
\text { \%MORTALITY }\end{array}$ \\
\hline ETHANOL & $\begin{array}{l}500 \\
250 \\
125\end{array}$ & $\begin{array}{l}6 \\
4 \\
3\end{array}$ & $\begin{array}{l}2 \\
2 \\
2\end{array}$ & $\begin{array}{l}60 \\
40 \\
30\end{array}$ & $\begin{array}{l}20 \\
20 \\
20\end{array}$ & $\begin{array}{l}50.00 \\
25.00 \\
12.50\end{array}$ & 29.16 \\
\hline CHLOROFORM & $\begin{array}{l}500 \\
250 \\
125 \\
\end{array}$ & $\begin{array}{l}6 \\
6 \\
2 \\
\end{array}$ & $\begin{array}{l}1 \\
1 \\
1\end{array}$ & $\begin{array}{l}60 \\
60 \\
20\end{array}$ & $\begin{array}{l}10 \\
10 \\
10 \\
\end{array}$ & $\begin{array}{l}55.56 \\
55.56 \\
11.11 \\
\end{array}$ & 40.74 \\
\hline $\begin{array}{l}\text { DISTILLED } \\
\text { WATER }\end{array}$ & $\begin{array}{l}500 \\
250 \\
125 \\
\end{array}$ & $\begin{array}{l}6 \\
3 \\
2 \\
\end{array}$ & $\begin{array}{l}1 \\
1 \\
1 \\
\end{array}$ & $\begin{array}{l}60 \\
30 \\
20 \\
\end{array}$ & $\begin{array}{l}10 \\
10 \\
10 \\
\end{array}$ & $\begin{array}{l}55.56 \\
22.22 \\
11.11 \\
\end{array}$ & 29.63 \\
\hline $\begin{array}{l}\text { PETROLEUM } \\
\text { ETHER }\end{array}$ & $\begin{array}{l}500 \\
250 \\
125 \\
\end{array}$ & $\begin{array}{l}6 \\
3 \\
2 \\
\end{array}$ & $\begin{array}{l}1 \\
1 \\
1 \\
\end{array}$ & $\begin{array}{l}60 \\
30 \\
20 \\
\end{array}$ & $\begin{array}{l}10 \\
10 \\
10 \\
\end{array}$ & $\begin{array}{l}55.56 \\
22.22 \\
11.11 \\
\end{array}$ & 29.63 \\
\hline METHANOL & $\begin{array}{l}500 \\
250 \\
125\end{array}$ & $\begin{array}{l}5 \\
4 \\
3\end{array}$ & $\begin{array}{l}2 \\
2 \\
2\end{array}$ & $\begin{array}{l}50 \\
40 \\
30\end{array}$ & $\begin{array}{l}20 \\
20 \\
20\end{array}$ & $\begin{array}{l}37.50 \\
25.00 \\
12.50\end{array}$ & 25.00 \\
\hline
\end{tabular}

For the values given in table 4 , the chloroform soluble fraction of Hyptis spicigera recorded the highest average mortality of $33.333 \%$ and was closely followed by the distilled water soluble fraction with an average mortality of $33.33 \%$. The petroleum ether soluble fraction of the plant presented the least average mortality of $28.56 \%$. From the stated values, it could be explained that the chloroform soluble fraction contains the most active component(s) of the plant, whereas the petroleum ether soluble fraction contains the least. However, the chloroform soluble fractions of both plants were found to be the most active fractions, while the ethanol soluble extract and the petroleum ether soluble fraction were the least active for Hyptis suaveolens and Hyptis spicigera respectively. Since the chloroform soluble fraction is identified to be responsible for protecting the cowpea seeds from being infested, and for causing the dead of the cowpea weevils, then there is a correlation between the feeding deterrent activity and toxicity to cowpea weevils

Table.4: Effects of Hyptis spicigera extracts on the mortality rates of cowpea weevils

\begin{tabular}{|l|l|l|l|l|l|l|l|}
\hline $\begin{array}{l}\text { SOLUBLE } \\
\text { SOLVENT } \\
\text { EXTRACT/ } \\
\text { FRACTION }\end{array}$ & $\begin{array}{l}\text { CONCENTRATION } \\
(\mu \mathrm{g} / \mathrm{ml})\end{array}$ & $\begin{array}{l}\text { TEST } \\
\text { MORTALITY }\end{array}$ & $\begin{array}{l}\text { CONTROL } \\
\text { MORTALTYY }\end{array}$ & $\begin{array}{l}\% \\
\text { TEST } \\
\text { MORTALTY }\end{array}$ & $\begin{array}{l}\text { \% } \\
\text { CONTROL } \\
\text { MORTALITY }\end{array}$ & $\begin{array}{l}\% \\
\text { MORTALITY }\end{array}$ & $\begin{array}{l}\text { MEAN \% } \\
\text { MORTALITY }\end{array}$ \\
\hline \multirow{3}{*}{ ETHANOL } & 500 & 5 & 1 & 50 & 10 & 44.44 & \\
& 250 & 4 & 1 & 40 & 10 & 33.33 & 29.627 \\
& 125 & 2 & 1 & 20 & 10 & 11.11 & \\
\hline \multirow{3}{*}{ CHLOROFORM } & 500 & 6 & 1 & 60 & 10 & 55.56 & \\
& 250 & 4 & 1 & 40 & 10 & 33.33 & 33.333 \\
& 125 & 2 & 1 & 20 & 10 & 11.11 & \\
\hline \multirow{2}{*}{ DISTILED } & 500 & 5 & 1 & 50 & 10 & 44.44 & \\
WATER & 250 & 4 & 1 & 40 & 10 & 33.33 & 33.330 \\
& 125 & 3 & 1 & 30 & 10 & 22.22 & \\
\hline \multirow{2}{*}{ PETROLEUM } & 500 & 6 & 3 & 60 & 30 & 42.85 & \\
ETHER & 250 & 5 & 3 & 50 & 30 & 28.57 & 28.567 \\
& 125 & 4 & 3 & 40 & 30 & 14.28 & \\
\hline \multirow{3}{*}{ METHANOL } & 500 & 5 & 2 & 50 & 20 & 37.50 & \\
& 250 & 4 & 2 & 40 & 20 & 25.00 & 25.000 \\
\hline
\end{tabular}




\section{CONCLUSION}

From the results obtained in the anti-feeding and mortality tests, it can be generally concluded that the soluble solvent extracts of the two plants were toxic to the cowpea weevils because these soluble extracts were able to kill the weevils or prevent them from feeding on the cowpeas seeds.

In all, the most toxic extracts to the cowpea weevils can be assigned to the chloroform soluble fractions of the two plants because the cowpea seeds treated with the chloroform soluble fractions recorded the least percentage consumption indices and the highest percentage mortalities. This is an indication that extracts of these plants could be used to protect cowpea seeds from damage.

\section{RECOMMENDATION}

It is therefore recommended that further research should be conducted on these two plants to help isolate the active compounds which could serve as pesticides for keeping the desirable qualities of cowpea seeds. This will provide a more environmentally-friendly pesticides to avoid the use of synthetic pesticides that leave residues on plants and in the soil that may be harmful to both humans and the environment at large. The Ministry of Food and Agriculture of Ghana must provide the needed funding and logistics in conducting further research into these two plant extracts used as replacements of the environmentally hazardous synthetic pesticides often used in Ghana. This would maintain environmental quality while protecting the rich biological diversities in the environment.

\section{REFERENCES}

[1] Alma-Ata (1978). "Traditional Medicine Programme". Report on $18^{\text {th }}$ annual session of World Health Organisation, Buenos Aires 114, 2.

[2] Amoako, K. P. (2010). Assessment of pesticides used to control insect pests and their effects on storage of cabbage: A case studies in Ejisu-Juaben municipal area, (MSc. thesis). Ghana: Kwame Nkrumah University of Science and Technology.

[3] Amoah, A. B.(2010).Efficacy of Ethonolic Extract of Thevetia peruviana(PERS) K-Schum.(Milk Bush)Root In The Control of Major Insect Pest of Cowpea(MSc thesis),Kwame Nkrumah University Of Science and Technology.

[4] Belmain, R. (2000). Chemistry of the lamiaceae family, Pharmaceutical Science,57, 115-119.

[5] Birkill, H.M. (1985).The useful plants of West Africa, London: Royal Botanic Gardens Kew, pp 12-13.

[6] Bouquet, A. (1969). Medicinal plants of Congo, London: Adam Delving, pp 3.
[7] Brice, E., Newmann, J. and Robinson, P. (1996). Grain Protectant Plants, Applied Ecology 5, 14-16.

[8] Chartterjee, A. ,Pakrashi, S.C. (1997). The treatise on Indian Medicinal Plants, New Delhi: University Press pp 15.

[9] Chopra, L. (1956). Medicinal Plants, London: McMillan, pp 109-115.

[10] Chukwujekwu J.C., Smith, P., Coombes, P.H., Mulholland, D.A. and Staden, J. Van. Antiplasmodial diterpenoid from the leaves of Hyptis suaveolens. Journal of Ethnopharmacology, 2005; 102(2): 295-7.

[11] Corey, E.J., Rajat, B.and Hisashil, U. (1964).Total synthesis of d,1-caryophyllene and d,1is ocaryophyllene. American Chemical Society 294, 86.

[12] Dalziel, J.M. (1937). The useful Plants of West Africa, London: MacMillan, pp 436-439.

[13] Dally, H., Doyen, J.T. and Purccell, A.H. (1998). Introduction to Insect Biology and biodiversity, New York: Oxford University Press, pp 273-300.

[14] Drees, B.M. and Jackman, J. (1999). Field Guide to Texas insects, Houston Texas: Gulf Publishing Company, pp 167.

[15] Eurekalert, B. (2009). New green pesticides, California: Thompson Learning Inc., pp 212.

[16] Essumang, D. K., Dodoo, D. K., Adokoh, C. K. and Fumador, F. A. (2008). Analysis of some pesticide residues in tomatoes in Ghana. Human and ecological risk as sessment (HERA), 14, (4): 796-806

[17] Fatope, M.O., Abdullahi, M. N., Fatima, M.M. (1995). Pesticidal Effects from Balamtes Aegyptiaca(L). Spectrum 2, 82-89.

[18] Fishel, F.M.,(2013). Pest Management and Pesticides: A Historical Perspective. http://edis.ifas.ufl.edu.

[19] Glover-Amengor, M. and Tetteh, F.M.(2007). Effects of Pesticide Application on Yield of Vegetables and Soil Microbial Communities, Applied Ecology 12, 4147.

[20] Graham-Bryce, I.J. (1981). The behaviour of Pesticides in soil, the chemistry of soil processes, New York: John Wiley and Sons Ltd, pp 44.

[21] Hipkins, P., Helfrisch, L.A., Weigmann, D.L., and Stinson, E.R. (1996). Pesticides and Aquatic Animals, A Guide to reading impacts on aqua systems, Pennsylvania: Aqua systems vigenra cooperatives extension, pp 101.

[22] Kellog, R.L., Nehringh, R., Grube, A., Gooss, D.W. and Plotkin, S. (2000). Environmental indicators of pesticides leaching and run-off from farm fields, New York: McGraw Hill, pp 3-10. 
[23] Kerharo, F.M and Bouquet, J.A. (1950).Toxic medicinal plants of Ivory Coast, Paris: Vigot Frères, pp 21-50

[24] Kiniuki, S. (2001). Effects of Organic Fertilisation and Pesticide Application on Growth and Yield of Field Grown rice for 10 years, Crop science, 7, 530 - 540.

[25] Kirtikar, K.R. and Basu, B.D. (1991). Indian Medicinal plants, New Delhi: Singh B. and Singh M.P Publishers, pp 20-32.

[26] Knutson, R. (1999).Economic Impacts of Reduced Pesticides in the United States, Sustaining the Earth 6, 216.

[27] Leonti, M.and Reduner, S. (2008). Beta-caryophyllene is a dietary cannabinoid, National Academy of Science 89,105 .

[28] Leroy, P., Juan, V., James, P. and Donald, L. (2009). A geographical Atlas of world weeds, New York: John Wiley and Sons, pp 391.

[29] Lobe, J. (2006). 'WHO urges DDT for malaria control strategies'.In: commondreams.org. (Inter Press Service), Proceedings of the WHO conference, Geneva, 16 September, 2006, pp 4-7.

[30] Malele, R.S., Mutayabarwa, C.K., Mwang, J.W,and Thioti, G.N. (2005). Compounds in Hyptis suaveolens, Essential oil Research 48, 14-20.

[31] Mandal, S.M., Mondal, K.C. Deys,S. and Pati, B.R.(2007). Antimicrobial activity of leaf extracts of Hyptis suaveolens (L) poit, Pharmaceutical Sciences 69,568-569.

[32] Miller, G. T. (2002). Living in the Environment(12th edition). Belmont: Wadsworth/Thoms on Learning. ISBN 5, 34-37

[33] Miller, G.T. (2004). Living In the Environment, California: Thompson Learning Inc., Pp 211-216.

[34] Mukherjee, K.S., Mukherjee, R.K. and Ghosh, P.K. (1984). Chemistry of Hyptis suaveolens, a pentacyclic triterpene, Natural Products 47, 377-378.

[35] Nojima, S., Shimomura, K., Honda, H., Yamamoto, I. and Oshawa, K. (2007). Contact Sex Hormone Component of Cowpea Weevil, Chemical Ecology 33, 923-933.

[36] Onayade, O.A. and Looman, A. (2003). Flavour and Fragrance, Useful plants 5, 101-105.

[37] Oparaeke, A.M. (2007). Effect of crude extracts of mixtures of different plant species in the control of Megalurothrips sjostedti Trybom and pod setting of cowpea plants, Archives of Phytopathology and Plant Protection, 40(3): 201-206.

[38] Othira, J.O.,Deng , A.L., Onek, L.A., Kennedy, J. and Omolo, E.O. (2008). Potential Application of Hyptis spicigera for Biological Control of Striga hermonthica
Infestation, African Agricultural Research 3 (10), 747752.

[39] Owens, K., Feldman, J., and Kepner J. (2010).Wide Range of Disease Linked to Pesticides Database supports policy shift from risk to alternatives assessment.Vol.30.No 2.page 14-21, www.beyondpesticides.org/health/pid-database.pdf

[40] Parson, W.T. and Anthbertson, E.G. (1992). Noxious weeds of Australia, Melbourne-Sydney: Inkata Press, Pp 692.

[41] Philips, T.W., Philips, J.K., Webster, F.X., Tang, .R. and Burkholder, W.E. (1996). Identification of sex pheromones from cowpea weevil, Callosobruchus maculatus and related studies of C. analis (coleopteran: Bruchidae), Chemical Ecology 22, 4445.

[42] Sanon, A. and Ilboudo, Z. (2006). Effects of Hyptis spicigera Lam on behaviour and development of cowpea weevils, Pest Management 52,117-123.

[43] Singh, B. K., and Walker, A. (2006). Microbial degradation of organophosphorus compounds. FEMS Microbiol. Rev. 30, 428-471.

[44] Sharma, P.P, Roy R. K, Anurag, Gupta, D. and Vipin K.S. Hyptis suaveolens (L.) poit: A phytopharmacological review, International Journal of Chemical and Pharmaceutical Sciences, 2013, Mar., Vol. 4 (1), pp 1

[45] Yussuf, A., Hassan, S.and Chris B. P. (2006). Parkia biglobosa fruit husk and Hyptis spicigera leaves for controlling root-knot (Meloidogyne incognita) in tomato,Tropical agriculture, 44(1-2), 83- 85.

[46] Yoganarasimhan, S.N. Hyptis Suaveolens. In:Srinivasan V, Kosal Ram N editors. Medicinal Plants of India. Vol. II. Bangalore: CyberMedia, 2000, pp. 282

[47] Zimmerman, E.C. (1999). Australian weevils, East Melbourne: Melbourne University Press, Pp 741. 